http://journal.uinsgd.ac.id/index.php/biodjati

\title{
POTENTIAL AND CHALLENGES ON AMPHIBIANS AND REPTILES RESEARCH IN WEST JAVA
}

\author{
Ganjar Cahyadi*1, Umilaela Arifin ${ }^{2}$
}

Received : June 07, 2019

Accepted : October 16, 2019

\section{DOI: 10.15575/biodjati.v4i2.4820}

${ }^{1}$ Museum Zoologi, School of Life Sciences and Technology (SITH), Institut Teknologi Bandung

Jl. Let. Jend. Purn. Dr. (HC) Mashudi No.1, Jatinangor, Kabupaten Sumedang 45363, Indonesia, phone: 02286010012

${ }^{2}$ Centrum für Naturkunde - Zoologisches Museum, Universität Hamburg

Edmund-Siemers-Allee 1, 20146 Hamburg, Germany

e-mail:

*lganjar@sith.itb.ac.id

umilaela@gmail.com

*Corresponding author
Abstract. West Java Province has the largest population amongst others in Java, and therefore land conversion rate in the region is increasing. Approximately 40\% of forest areas in West Java has been converted between 1990-2015. As a consequence, the number of biodiversity in the region is decreasing, including amphibians and reptiles. These groups play an important role in the food chain of an ecosystem, and are very sensitive to environmental changes. However, comprehensive research on amphibian and reptile species in West Java is suboptimal. Visual Encounter Survey has performed in seven districts in West Java for one month and has recorded 26 amphibian species and 27 reptile species. These species were including Javan endemic species (for example: Fejervarya iskandari, Huia masonii, Limnonectes microdiscus, Megophrys montana, and Microhyla achatina), introduced species (Calotes versicolor), and species with a new distribution record (Leptophryne borbonica and Kalophrynus minusculus). In addition, cryptic species (Genus Leptophryne and Cyrtodactylus), which are interesting for further studies, were observed. This study has demonstrated that the potential of a comprehensive study of amphibian and reptile species in West Java is great. Apart from this, conserving the biodiversity in the region also challenging due to the high rate in land conversion.

Keywords: biodiversity, conservation, endemic spesies, herpetofauna, introduced species, taxonomy

\section{Citation}

Cahyadi, G. \& Arifin, U. (2019). Potential and Challenges on Amphibians and Reptiles Research in West Java. Jurnal Biodjati, 4(2), 149-162

\section{INTRODUCTION}

West Java is the second largest province on the island of Java, comprises approximately $35,377.76 \mathrm{~km}^{2}$. The Central Statistical Bureau of Indonesia (BPS, 2017) has recorded \pm 43 million inhabitants in this province, with population growth rate of around $1.54 \%$ per year. Between 2000-2010, the population density in the region has increased by $21 \%$ (BPS, 2017). As a consequence, deforestation and land use change in West Java continues to date. Approximately $40 \%$ of forest areas in West Java has been lost between 1990-2015 (Prasetyo et al., 2009; Agaton et al., 2016; Higginbottom et al., 2019). Thus, tremendous number of habitats were dramatically disappearing along with its biodiversity, and therefore highly affected the stability of the ecosystem (Gibson et al., 2011; Mace et al., 2012). Amphibians and reptiles (herpetofauna) are amongst the most vulnerable groups of ani- 


\section{JURNAL BIDDJATI}

http://journal.uinsgd.ac.id/index.php/biodjati

mals that affected by these habitats destruction (Valencia-Aguilar et al., 2013). Herpetofauna plays an important role in the ecosystem, e.g., providing ecosystem services: as pollinators, as seed dispersers, and as food chain compilers, either as predators or prey (Hof et al., 2011; Cortés-Gomez et al., 2015). Additionally, herpetofauna considered as bioindicators because they are very sensitive to environmental changes (Schneider et al., 2013; Saber et al., 2017). Therefore, their existence in the nature cannot be neglected, and conserving the species and its habitats must be prioritized (Sodhi et al., 2010). Proper conservation strategies can only be applied if the baseline data used as reference (e.g., biology, habitat, ecology, population and distribution) for the species is complete (IUCN Standards and Petitions Subcommittee, 2017; IUCN, 2019). To date, exploration and comprehensive research on amphibians and reptiles in West Java is very limited and only focuses on the national park regions (Kusrini, 2013). Research on amphibians and reptiles in Java during the last five years (2014-2019), e.g. Riyanto et al. (2014); Riyanto \& Kurniati (2014); Riyanto et al. (2015); Hartmann et al. (2016); Kieckbusch et al. (2016); Hamidy et al. (2018); Riyanto et al. (2019), have demonstrated that herpetofauna diversity in the region is still underestimated. Thus, in this paper we will discuss the potential of amphibians and reptiles research in West Java. Challenges faced along with the rapid rate of land conversion will also be discussed.

\section{MATERIALS AND METHODS}

Data collection was conducted between 1-31 August 2018. Seven districts (Kabupaten/Kota) in West Java were chosen for this study. A total of 18 sites were selected to represent various types of land use and only sampled once: Kabupaten Bandung $(\mathrm{N}=3)$, Kab. Bandung Barat $(\mathrm{N}=3)$, Kab. Bogor $(\mathrm{N}$ $=1)$, Kab. Garut $(\mathrm{N}=1)$, Kab. Subang $(\mathrm{N}=$ 1), Kab. Sumedang $(\mathrm{N}=5)$, and Kota Bandung $(\mathrm{N}=4)$ (Figure 1). Variations in land use and habitat types were selected accordingly based on this following criteria: (1) conservation/non-conservation areas; (2) i - highland rainforest (HF), ii - lowland rainforest (LF), iii - karst hill (KA), iv - waterfall (WF), v rice field (RF), vi - plantation (PL), and vii - settlement (SE) (See Table 1).

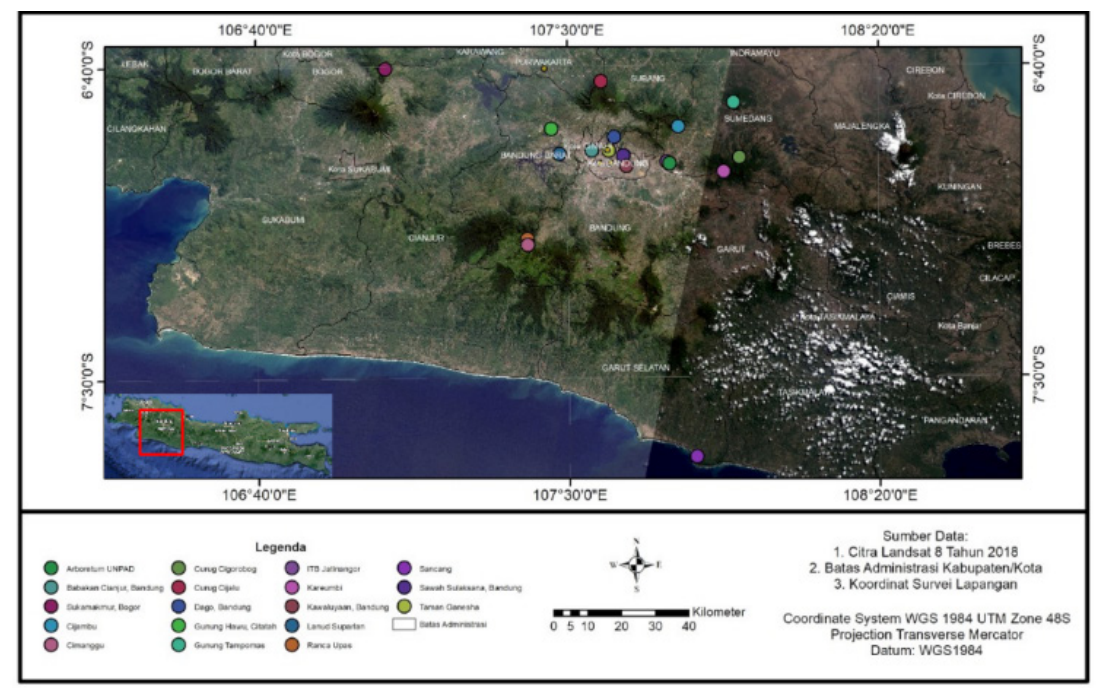

Figure 1. Map showing sampling localities for this study 


\section{JURNAL BIDDJATI}

http://journal.uinsgd.ac.id/index.php/biodjati

Table 1. Information of sampling localities for this study. HF = highland rainforest; $\mathrm{LF}=$ lowland rainforest; $\mathrm{KA}=$ karst hill; $\mathrm{WF}=$ waterfall; $\mathrm{RF}=$ rice field; $\mathrm{PL}=$ plantation; $\mathrm{SE}=$ settlement.

\begin{tabular}{|c|c|c|c|c|c|c|c|c|c|c|}
\hline \multirow{2}{*}{ No } & \multirow{2}{*}{ Sampling localities } & \multirow{2}{*}{ District } & \multicolumn{7}{|c|}{ Habitat Type } & \multirow{2}{*}{$\begin{array}{c}\text { Conservation } \\
\text { Area* }\end{array}$} \\
\hline & & & $\mathrm{HF}$ & LF & KA & WF & $\mathrm{RF}$ & PL & $\mathrm{SE}$ & \\
\hline 1 & $\overline{\text { Cimanggu }}$ & \multirow{3}{*}{$\begin{array}{c}\text { Kab. } \\
\text { Bandung }\end{array}$} & $\sqrt{ }$ & - & - & - & - & $\sqrt{ }$ & - & Yes \\
\hline 2 & Kareumbi & & $\sqrt{ }$ & - & - & - & - & $\sqrt{ }$ & - & Yes \\
\hline 3 & Ranca Upas & & $\sqrt{ }$ & - & - & - & - & $\sqrt{ }$ & - & No \\
\hline 4 & Dago & \multirow{3}{*}{$\begin{array}{c}\text { Kab. } \\
\text { Bandung } \\
\text { Barat }\end{array}$} & - & - & - & - & - & $\sqrt{ }$ & $\sqrt{ }$ & No \\
\hline 5 & Gunung Hawu, Citatah & & - & - & $\sqrt{ }$ & - & $\sqrt{ }$ & $\sqrt{ }$ & - & No \\
\hline 6 & Lanud Suparlan & & - & - & - & - & $\sqrt{ }$ & $\sqrt{ }$ & $\sqrt{ }$ & No \\
\hline 7 & Sukamakmur & $\begin{array}{l}\text { Kab. } \\
\text { Bogor }\end{array}$ & - & - & - & - & $\sqrt{ }$ & - & - & No \\
\hline 8 & $\begin{array}{l}\text { Leuweung Sancang } \\
\text { Nature Reserve }\end{array}$ & Kab. Garut & - & $\sqrt{ }$ & - & - & - & - & - & Yes \\
\hline 9 & Curug Cijalu & $\begin{array}{l}\text { Kab. } \\
\text { Subang }\end{array}$ & $\sqrt{ }$ & - & - & $\sqrt{ }$ & - & - & - & No \\
\hline 10 & Arboretum UNPAD & \multirow{5}{*}{$\begin{array}{c}\text { Kab. } \\
\text { Sumedang }\end{array}$} & - & - & - & - & $\sqrt{ }$ & $\sqrt{ }$ & $\sqrt{ }$ & No \\
\hline 11 & Cijambu & & $\sqrt{ }$ & - & - & - & $\sqrt{ }$ & $\sqrt{ }$ & $\sqrt{ }$ & No \\
\hline 12 & Curug Cigorobog & & $\sqrt{ }$ & - & - & $\sqrt{ }$ & - & $\sqrt{ }$ & - & Yes \\
\hline 13 & Gunung Tampomas & & $\sqrt{ }$ & - & - & $\sqrt{ }$ & - & $\sqrt{ }$ & - & Yes \\
\hline 14 & ITB Jatinangor & & - & - & - & - & $\sqrt{ }$ & $\sqrt{ }$ & $\sqrt{ }$ & No \\
\hline 15 & Babakan Cianjur & \multirow{4}{*}{$\begin{array}{c}\text { Kota } \\
\text { Bandung }\end{array}$} & - & - & - & - & $\sqrt{ }$ & - & $\sqrt{ }$ & No \\
\hline 16 & Kawaluyaan & & - & - & - & - & $\sqrt{ }$ & - & $\sqrt{ }$ & No \\
\hline 17 & Sulaksana & & - & - & - & - & $\sqrt{ }$ & - & $\sqrt{ }$ & No \\
\hline 18 & Taman Ganesha & & - & - & - & - & - & $\sqrt{ }$ & $\sqrt{ }$ & No \\
\hline
\end{tabular}

*)Retrieved from BBKSDA JABAR (2019); $\sqrt{ }$ ) Observed; -) Not observed

The Visual Encounter Survey (VES) method was employed during the day and night to visually record the presence of amphibians and reptiles. We performed VES by walking along habitat areas (e.g., rivers, forest paths or rice fields) for \pm 3.5 hours. Each site was sampled only once (no repetition). We recorded any amphibians and reptiles, including several baseline data such as: location and time of observation, weather condition, habitat description, species name, body size, sex, and individual activities (Heyer et al., 1994). Daytime observations (10.00-13.00 Jurnal Biodjati 4(2):149-162, November 2019
WIB) were focused on diurnal reptiles whereas night observations (18.30-22.00 WIB) for nocturnal amphibians and reptiles. Each individual of amphibians and reptiles were captured by hand or by using a snake hook and garden rakes, then were documented using a camera (digital pocket or smartphone) with flash light and/ or headlamps for lighting. For species that were doubtful or unable to identify in the field, additional morphological characters that are important for identification in the laboratory (see Hartmann et al., 2016; Arifin et al., 2018a) were recorded. For mer- 


\section{JURNAL BIDDJATI}

http://journal.uinsgd.ac.id/index.php/biodjati

istic characters: number of scales on the head, scales on the dorsal region of the body, scales on the fourth toe, scales before the cloaca and on the femoral region (precloacofemoral scales), and scales on the tail. For morphometric characters: body length (SVL), limbs, tail (TL; particularly for reptiles), length of the head, and diameter of eyes; all measurement were using a caliper with accuracy of $0.02 \mathrm{~mm}$. After examination, all specimens were released into their original habitat. In the laboratory, we use several books to confirm the identity of doubtful individuals: Iskandar (1998); Grismer (2011); Kusrini (2013); and De Lang (2017). Data from this study was analyzed using EstimateS 9.1.0 (Colwell, 2013) to obtain species accumulation curves. Additionally, we did estimation analyses curve to project the total number of species if data collection was continued up to 60 days.

\section{RESULTS AND DISCUSSION}

Based on a total of 30 observation days in 18 selected localities in West Java, we recorded 53 species of amphibians and reptiles (amphibians: 26 species, 6 families, see Table 2; reptiles: 27 species, 8 families, see Table 3 ). Within this time period, the number of species seems steadily increase, either for amphibians, reptiles, or both amphibians and reptiles (Figure 2). Even if we continue the observation up to 60 days or more, the possibility to find more species in the region is very likely (Figure 2).

We refer to IUCN (2019) on assigning conservation status of each species obtained in this study. Amongst all species recorded in this study, 25 of 26 species of amphibian and 17 of 27 species of reptiles were registered in the Red List categories (Tables 2 \& 3). Most of those herpetofauna species were categorized as Least Concern (LC), and no species require a special conservation action at this point. Rhacophorus reinwardtii was the only species that categorized as Near Threatened (NT). The remaining one species of amphibian and ten species of reptiles were categorized as Not Evaluated (NE) to date (Tables $2 \& 3$ ). Concerning status for trading and as protected species, we refer to CITES, and the Indonesian regulation (Permen No.106/2018 or P.106, which is an updated version of Annex PP No.7/1999) respectively. Amongst all species recorded in this study, only $M a$ layopython reticulatus and Naja sputatrix were listed in CITES-Appendix II (Tables 2 \& 3) and no species listed in P.106. Other than abovementioned status, we also found five Javan endemic species (Fejervarya iskandari, Huia masonii, Limnonectes microdiscus, Megophrys montana, and Microhyla achatina) and one introduced species (Calotes versicolor). Furthermore, two possible cryptic species such as Leptophryne borbonica and Cyrtodactylus spp. were observed during the study (Tables 2 \& 3).

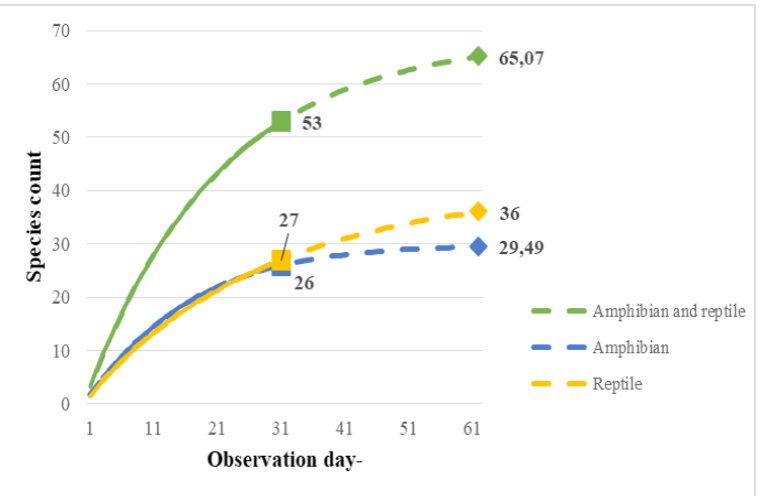

Figure 2. Species accumulation curves showing the number of amphibians and reptiles species through time (number of observation days). Solid-line represent actual number of species observed during the study; dashed-line represent estimated number of species observed if observation continued. Yellow: reptiles, blue: amphibians, green: amphibians and reptiles. 


\section{JURNAL BIDDJATI}

http://journal.uinsgd.ac.id/index.php/biodjati

Table 2. List of amphibian species observed in seven districts in West Java: $\mathrm{BO}=\mathrm{Kabupaten}$ (Kab.) Bogor; $\mathrm{BB}=\mathrm{Kab}$. Bandung Barat; $\mathrm{BD}=$ Kota Bandung; $\mathrm{KB}=\mathrm{Kab}$. Bandung; $\mathrm{SU}=\mathrm{Kab}$. Subang; $\mathrm{SM}=\mathrm{Kab}$. Sumedang; GA= $\mathrm{Kab}$. Garut. Information concerning conservation status $(\mathrm{LC}=$ Least Concern; NE= Not Evaluated; NT= Near Threatened) following database of IUCN (2019), trading status of CITES (UNEP-WCMC, 2014), and P.106/2018 (Kementrian Lingkungan Hidup dan Kehutanan, 2019) are provided. Species marked with star (*) is endemic; with hyphen (-) is un-observed/not listed; with vau (V) is observed.

\begin{tabular}{|c|c|c|c|c|c|c|c|c|c|c|c|}
\hline \multirow{2}{*}{ No } & \multirow{2}{*}{$\frac{\text { Species Name }}{\text { AMPHIBIAN }}$} & \multicolumn{3}{|c|}{ Conservation Status } & \multicolumn{7}{|c|}{ Localities } \\
\hline & & IUCN & CITES & P.106 & $\mathrm{BO}$ & BB & $\mathrm{BD}$ & $\mathrm{KB}$ & $\mathrm{SU}$ & SM & $\overline{\mathrm{GA}}$ \\
\hline & Bufonidae & & & & & & & & & & \\
\hline 1 & Duttaphrynus melanostictus & LC & - & - & - & $\mathrm{V}$ & V & - & - & V & - \\
\hline 2 & Ingerophrynus biporcatus & LC & - & - & - & - & - & - & - & - & $\mathrm{V}$ \\
\hline 3 & Leptophryne borbonica & LC & - & - & - & - & - & - & - & $\mathrm{V}$ & - \\
\hline \multirow[t]{2}{*}{4} & Phrynoidis asper & LC & - & - & - & - & - & - & $\mathrm{V}$ & $\mathrm{V}$ & - \\
\hline & Dicroglossidae & & & & & & & & & & \\
\hline 5 & Fejervarya cancrivora & LC & - & - & - & - & $\mathrm{V}$ & $\mathrm{V}$ & - & - & - \\
\hline 6 & Fejervarya limnocharis & LC & - & - & - & $\mathrm{V}$ & V & - & - & V & $\mathrm{V}$ \\
\hline 7 & Fejervarya iskandari* & LC & - & - & - & $\mathrm{V}$ & - & - & - & - & - \\
\hline 8 & Limnonectes kuhlii & $\mathrm{LC}$ & - & - & - & - & - & $\mathrm{V}$ & $\mathrm{V}$ & $\mathrm{V}$ & - \\
\hline 9 & Limnonectes macrodon & LC & - & - & - & $\mathrm{V}$ & - & - & - & $\mathrm{V}$ & $\mathrm{V}$ \\
\hline 10 & Limnonectes microdiscus* & LC & - & - & - & - & - & $\mathrm{V}$ & - & - & $\mathrm{V}$ \\
\hline 11 & Occidozyga lima & LC & - & - & - & $\mathrm{V}$ & - & - & - & - & - \\
\hline \multirow[t]{2}{*}{12} & Occidozyga sumatrana & $\mathrm{LC}$ & - & - & - & - & - & - & - & - & $\mathrm{V}$ \\
\hline & Megophryidae & & & & & & & & & & \\
\hline 13 & Leptobrachium hasseltii & LC & - & - & - & - & - & $\mathrm{V}$ & $\mathrm{V}$ & $\mathrm{V}$ & $\mathrm{V}$ \\
\hline \multirow[t]{2}{*}{14} & Megophrys montana* & LC & - & - & - & - & - & - & - & $\mathrm{V}$ & - \\
\hline & Microhylidae & & & & & & & & & & \\
\hline 15 & Kalophrynus minusculus & LC & - & - & - & - & - & - & - & - & $\mathrm{V}$ \\
\hline 16 & Kaloula baleata & LC & - & - & - & - & V & - & - & - & - \\
\hline 17 & Microhyla achatina* & LC & - & - & - & $\mathrm{V}$ & - & $\mathrm{V}$ & - & $\mathrm{V}$ & $\mathrm{V}$ \\
\hline 18 & Microhyla palmipes & LC & - & - & - & - & - & $\mathrm{V}$ & - & - & - \\
\hline \multirow[t]{2}{*}{19} & Microhyla sp. & $\mathrm{NE}$ & - & - & - & - & - & - & - & - & $\mathrm{V}$ \\
\hline & Ranidae & & & & & & & & & & \\
\hline 20 & Amnirana nicobariensis & LC & - & - & - & - & - & $\mathrm{V}$ & - & $\mathrm{V}$ & $\mathrm{V}$ \\
\hline 21 & Chalcorana chalconota & $\mathrm{LC}$ & - & - & - & $\mathrm{V}$ & V & $\mathrm{V}$ & $\mathrm{V}$ & $\mathrm{V}$ & $\mathrm{V}$ \\
\hline 22 & Huia masonii* & LC & - & - & - & - & - & $\mathrm{V}$ & $\mathrm{V}$ & $\mathrm{V}$ & - \\
\hline \multirow[t]{2}{*}{23} & Odorrana hosii & LC & - & - & - & - & - & - & $\mathrm{V}$ & $\mathrm{V}$ & - \\
\hline & Rhacophoridae & & & & & & & & & & \\
\hline 24 & Philautus aurifasciatus & LC & - & - & - & - & - & $\mathrm{V}$ & - & - & - \\
\hline 25 & Polypedates leucomystax & LC & - & - & - & $\mathrm{V}$ & $\mathrm{V}$ & $\mathrm{V}$ & - & $\mathrm{V}$ & - \\
\hline \multirow[t]{2}{*}{26} & Rhacophorus reinwardtii & NT & - & - & - & - & - & $\mathrm{V}$ & - & $\mathrm{V}$ & - \\
\hline & Total & & & & 0 & 8 & 6 & 12 & 6 & 15 & 11 \\
\hline
\end{tabular}




\section{JURNAL BIDDJATI}

http://journal.uinsgd.ac.id/index.php/biodjati

Table 3. List of reptile species observed in seven districts in West Java: $\mathrm{BO}=$ Kabupaten Bogor; $\mathrm{BB}=\mathrm{Kab}$. Bandung Barat; $\mathrm{BD}=$ Kota Bandung; KB=Kab. Bandung; $\mathrm{SU}=\mathrm{Kab}$. Subang; $\mathrm{SM}=\mathrm{Kab}$. Sumedang; GA= Kab. Garut. Information concerning conservation status ( $\mathrm{LC}=$ Least Concern; $\mathrm{NE}=$ Not Evaluated) following database of IUCN (2019), trading status of CITES (UNEP-WCMC, 2014), and P.106/2018 (Kementrian Lingkungan Hidup dan Kehutanan, 2019) are provided. Species marked with double star (**) is introduced; with hyphen (-) is un-observed/not listed; with vau (V) is observed.

\begin{tabular}{|c|c|c|c|c|c|c|c|c|c|c|c|}
\hline \multirow{2}{*}{ No } & \multirow{2}{*}{$\begin{array}{c}\text { Species Name } \\
\text { REPTILE }\end{array}$} & \multicolumn{3}{|c|}{ Conservation Status } & \multicolumn{7}{|c|}{ Localities } \\
\hline & & IUCN & CITES & P.106 & $\mathrm{BO}$ & $\mathrm{BB}$ & $\mathrm{BD}$ & KB & SU & $\mathrm{SM}$ & GA \\
\hline & Agamidae & & & & & & & & & & \\
\hline 1 & Bronchocela jubata & $\mathrm{LC}$ & - & - & - & $\mathrm{V}$ & $\mathrm{V}$ & - & $\mathrm{V}$ & $\mathrm{V}$ & - \\
\hline 2 & Calotes versicolor $* *$ & $\mathrm{NE}$ & - & - & - & $\mathrm{V}$ & $\mathrm{V}$ & - & - & $\mathrm{V}$ & - \\
\hline 3 & Draco volans & $\mathrm{LC}$ & - & - & - & - & - & - & - & $\mathrm{V}$ & - \\
\hline \multirow[t]{2}{*}{4} & Pseudocalotes tympanistriga & $\mathrm{NE}$ & - & - & - & - & - & $\mathrm{V}$ & - & $\mathrm{V}$ & - \\
\hline & Colubridae & & & & & & & & & & \\
\hline 5 & Ahaetulla prasina & $\mathrm{LC}$ & - & - & V & $\mathrm{V}$ & - & - & - & $\mathrm{V}$ & - \\
\hline 6 & Boiga drapiezii & $\mathrm{LC}$ & - & - & - & - & - & - & - & - & $\mathrm{V}$ \\
\hline 7 & Coelognathus flavolineatus & $\mathrm{LC}$ & - & - & - & - & $\mathrm{V}$ & - & - & - & - \\
\hline 8 & Dendrelaphis pictus & $\mathrm{NE}$ & - & - & - & - & - & - & - & $\mathrm{V}$ & $\mathrm{V}$ \\
\hline 9 & Lycodon capucinus & $\mathrm{LC}$ & - & - & - & - & V & - & - & - & - \\
\hline 10 & Rhabdophis chrysargos & $\mathrm{LC}$ & - & - & $\mathrm{V}$ & - & - & - & - & - & - \\
\hline 11 & Xenochrophis melanzostus & $\mathrm{LC}$ & - & - & - & $\mathrm{V}$ & - & - & - & - & - \\
\hline 12 & Xenochrophis trianguligerus & $\mathrm{LC}$ & - & - & - & - & - & $\mathrm{V}$ & - & - & - \\
\hline \multirow[t]{2}{*}{13} & Xenochrophis vittatus & $\mathrm{LC}$ & - & - & - & $\mathrm{V}$ & - & - & - & - & - \\
\hline & Elapidae & & & & & & & & & & \\
\hline \multirow[t]{2}{*}{14} & Naja sputatrix & $\mathrm{LC}$ & App.II & - & - & - & - & - & - & $\mathrm{V}$ & - \\
\hline & Gekkonidae & & & & & & & & & & \\
\hline 15 & Cyrtodactylus sp.1 "Cigorobog" & $\mathrm{NE}$ & - & - & - & - & - & - & - & $\mathrm{V}$ & - \\
\hline 16 & Cyrtodactylus sp.2 "Kareumbi" & $\mathrm{NE}$ & - & - & - & - & - & $\mathrm{V}$ & - & - & - \\
\hline 17 & Cyrtodactylus marmoratus & $\mathrm{NE}$ & - & - & - & - & - & $\mathrm{V}$ & - & - & - \\
\hline 18 & Gehyra mutilata & $\mathrm{NE}$ & - & - & - & - & - & - & - & $\mathrm{V}$ & - \\
\hline 19 & Gekko gecko & $\mathrm{NE}$ & - & - & - & $\mathrm{V}$ & - & - & - & - & $\mathrm{V}$ \\
\hline 20 & Hemidactylus frenatus & $\mathrm{LC}$ & - & - & - & $\mathrm{V}$ & $\mathrm{V}$ & $\mathrm{V}$ & $\mathrm{V}$ & $\mathrm{V}$ & $\mathrm{V}$ \\
\hline \multirow[t]{2}{*}{21} & Hemidactylus platyurus & $\mathrm{NE}$ & - & - & - & - & $\mathrm{V}$ & - & - & $\mathrm{V}$ & - \\
\hline & Lacertidae & & & & & & & & & & \\
\hline \multirow[t]{2}{*}{22} & Takydromus sexlineatus & $\mathrm{LC}$ & - & - & - & $\mathrm{V}$ & $\mathrm{V}$ & - & - & $\mathrm{V}$ & - \\
\hline & Pareidae & & & & & & & & & & \\
\hline \multirow[t]{2}{*}{23} & Pareas carinatus & $\mathrm{LC}$ & - & - & - & - & - & - & - & V & - \\
\hline & Pythonidae & & & & & & & & & & \\
\hline \multirow[t]{2}{*}{24} & Malayopython reticulatus & $\mathrm{LC}$ & App.II & - & - & $\mathrm{V}$ & - & - & - & - & - \\
\hline & Scincidae & & & & & & & & & & \\
\hline 25 & Eutropis multifasciata & $\mathrm{LC}$ & - & - & - & - & $\mathrm{V}$ & $\mathrm{V}$ & - & $\mathrm{V}$ & - \\
\hline 26 & Eutropis rugifera & $\mathrm{LC}$ & - & - & - & - & - & - & - & $\mathrm{V}$ & - \\
\hline \multirow[t]{2}{*}{27} & Tytthoscincus cf. temmincki & $\mathrm{NE}$ & - & - & - & - & - & - & - & $\mathrm{V}$ & - \\
\hline & Total & & & & 2 & 8 & 9 & 6 & 2 & 16 & 4 \\
\hline
\end{tabular}




\section{JURNAL BIDDJATI}

http://journal.uinsgd.ac.id/index.php/biodjati

\section{Amphibians and Reptiles Diversity in West Java}

To date, 37 species of amphibians (Iskandar, 1998; Riyanto \& Kurniati, 2014; Hamidy et al., 2018; Frost, 2019) and 51 species of reptiles (Uetz et al., 2019) have been recognized from West Java. Thus, the number of species recorded in this study represents only $70.3 \%$ and $53 \%$ of the list of currently recognized species. It means that the number of species in this region is very likely to increase if more sampling efforts are performed, as also shown in the species accumulation curve (Figure 2). Increasing the number of herpetofaunal research in West Java will potentially help to reveal and document many more hidden diversity in this region. Finding a new recorded species as well as new candidate species are very likely to happen, which has been shown in previous research for the last two decades, for example Mumpuni (2001), Kurniati (2002, 2003), Riyanto (2008), Kusrini (2013), and Kusrini et al. (2017). Unfortunately all of these research were conducted in the national parks with highland and mountainous forest habitats. Other conservation areas in West Java (non-national park, $\mathrm{N}=50$ ) have no record of its amphibians and reptiles diversity, although $9.43 \%$ of forest areas in West Java are covered by these 50 conservation areas, including 5 areas in Banten (BBKSDA JABAR, 2018, 2019). Future herpetofaunal research should not only focuses in the national parks, but also other conservation areas as well as non-conservation areas. Thorough sampling in various type of habitats and various land use are necessary for complete species documentation that is beneficial to assess the true diversity of amphibians and reptiles in the whole region. Many studies (e.g., Veith et al., 2001; Riyanto \& Kurniati, 2014) have demonstrated that even in the disturbed areas, such as rice fields, the potential of find- ing a new species is still very high. Thus, we are strongly agree that conducting research in non-conservation areas is as important as in the conservation areas.

\section{Conservation Status of Amphibians and Reptiles in West Java}

Documenting species diversity in West Java is undoubtfully crucial nowadays where the availability of habitats are rapidly shrinking (Higginbottom et al., 2019). Numerous amphibian and reptile species might have disappeared even before they were discovered (Iskandar \& Erdelen, 2006; Kusrini, 2007). Species documentation is an important foundation of further studies on biology and ecological aspects of the species, e.g., life cycle, diet, behavior, habitat (Fleming \& Aagaard, 1993), and also important in determining the original distribution of species which is native or introduced to the particular area (Kolbe et al., 2013). These information are indispensable to properly design conservation priorities for each species, particularly for reptiles (See Table 3). Not much information available for reptiles to date, therefore conservation status of numerous reptile species cannot be evaluated (Hamidy et al., 2018; IUCN, 2019). Even CITES (UNEP-WCMC, 2014) considered that no monitoring are yet required for these species. In contrary, the number of amphibians and reptiles trade, especially those from Java, continues to increase, either for consumption or pets (Kusrini \& Alford, 2006; Kusrini, 2007). The presence of Calotes versicolor as introduced lizard species in Java may indicates the effect of pet trade to its establishment in non-native area since this species is listed as one of the main commodities of exotic reptile trade (Kolbe et al., 2013; Sy, 2015). In addition, this species seems highly adaptable to urban habitat (Lever, 2003) and greatly abundant in an open area (e.g., mil- 


\section{JURNAL BIDDJATI}

http://journal.uinsgd.ac.id/index.php/biodjati

itary runway area in Lanud Suparlan, Kab. Bandung Barat; personal observation). As a consequence, native species that share similar type of habitat might be threatened (e.g., Bronchocela jubata; Takydromus sexlineatus). Hence, population management of this introduced species is paramount. We believe that Indonesian Government (e.g., Ministry of Environment and Forestry) should have played an important role in regulating each recognized species in Indonesia, especially in assigning its conservation status. Unfortunately until now, only 38 of 1222 recognized amphibian and reptile species in Indonesia have been identified as protected species under the Indonesian Law (Frost, 2019; Kementrian Lingkungan Hidup dan Kehutanan, 2019; Uetz et al., 2019). These species are protected because they are known as valuable pet species (e.g., Varanus spp.; [Koch et al., 2013]) or highly consumable species (e.g., for food or medicine, such as turtles and tortoises [Chen et al., 2009; Simoons, 2014]). The remaining species (not protected) are often underestimated, usually widespread species or species that has never been assessed for its benefit, including direct benefit for human. Thus they are generally marked as Least Concerned species and its occurrence in nature are often neglected (e.g., amphibian). Until now, Indonesian Government opted for listing all amphibians as unprotected animals, except for Leptophryne cruentata that has recently marked as protected species through PP No.7/1999 and Permen No.106/2018 (Hamidy et al., 2018;
Kementrian Lingkungan Hidup dan Kehutanan, 2019) after thorough assessment by IUCN Species Survival Commission Amphibian Specialist Group 2019 (2019).

\section{Endemic Species of Amphibians and Rep- tiles in West Java}

Focusing research on endemic species is also a challenge. In High Conservation Values (HCV) approach - a widely used tool for conservation, information concerning endemic species is often taken into account for final decision (Senior et al., 2015). To date, a total of 24 endemic species of amphibians and reptiles has been recorded in Java (Iskandar, 1998; Frost, 2019; Uetz et al., 2019). Among those, Huia masonii and Megophrys montana (Figure 3), are the two species that live in highland and mountainous forest habitats (Iskandar, 1998). Unfortunately, deforestation in West Java still continues and has reached several mountainous areas and therefore both species are significantly threatened. Moreover, $H$. masonii seems to be a specialists for fast-flowing stream habitats and characterized by unique morphological adaptation in their larval form (Arifin, 2018). This species is highly abundant in primary forest and less abundant in disturbed areas (personal observation), indicating how sensitive this species to any change in microhabitats. Other than that, recent studies have demonstrated that $H$. masonii might have potentially more than one species (Arifin, 2018; Arifin et al., 2018b).

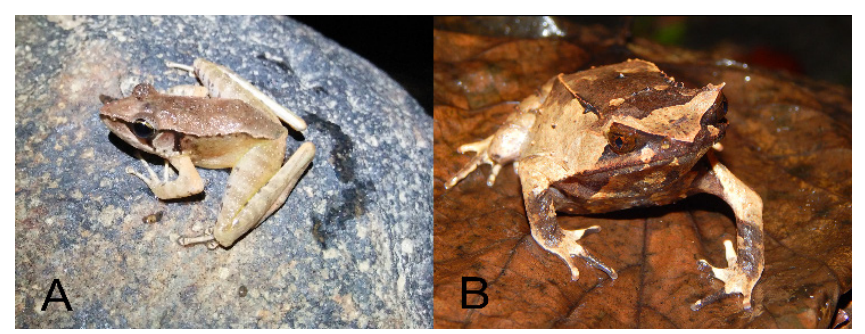

Figure 3. The endemic species of Java Island: A. Huia masonii; B. Megophrys montana (Photos: G. Cahyadi) 


\section{JURNAL BIDDJATI}

http://journal.uinsgd.ac.id/index.php/biodjati

\section{Cryptic Species of Amphibians and Rep- tiles in West Java}

Herpetofauna with cryptic or morphologically similar species are commonly found in the tropics (Bossuyt \& Milinkovitch, 2002; Bickford et al., 2007). This group usually treated as single species with widespread geographical distribution (see Bain et al., 2003; Stuart et al., 2006; Funk et al., 2012). Integrative taxonomy and broad sampling have been recommended to solve phylogenetic problems within cryptic species (Arifin et al. 2018b). Validating doubtful species identity is very important for effective conservation measures (IUCN Standards and Petitions Subcommittee, 2017). False identification will cause other information related to the species (e.g., taxonomy, biology, ecology, distribution) also incorrect. The discovery of the Leptophryne borbonica and Cyrtodactylus spp. in this study is very promising for further research opportunities (e.g., taxonomy, ecology and population distribution). Indonesia has only three recognized species of Leptophryne and all of them share similar morphology and similar type of habitats. L. borbonica has the widest geographical distribution (Sumatra, Borneo, and Java), whereas the other two species, L. cruentata and L. javanica are endemic to Java (Hamidy et al., 2018). The latter two species have narrow geographical distribution and were recorded from highland or mountain forests with particular type of habitats. These species live in rocky streams with waterfalls in montane forests in the island of Java (Hamidy et al., 2018). Based on these information, the two Leptophryne species are categorized as Critically Endangered and Endangered species, respectively (Hamidy et al., 2018; IUCN, 2019). Hamidy et al. (2018), however, suggested that L. borbonica from Sumatra and Kalimantan is probably a distinct lineage than the one from Java in their phylogenetic anal- yses, and thus further research is required. In the case of Cyrtodactylus, the species known from Java is often associated with C. marmoratus. Recent molecular studies have actually indicated several potential undescribed lineages within Cyrtodactylus (Hartmann et al., 2016; O'Connell et al., 2019). During the last five years (2014-2019), at least three new species of Cyrtodactylus has been described from central and eastern parts of Java (Riyanto et al., 2014, 2015; Hartmann et al., 2016). Until this study was conducted, molecular study of O'Connell et al. (2019) was the only study that included samples from West Java. In our study, we found three Cyrtodactylus (Cyrtodactylus sp.1 "Cigorobog", Cyrtodactylus sp.2 "Kareumbi", and C. marmoratus) from Curug Cigorobog (Kab. Sumedang; 780 $\mathrm{m}$ asl), Kareumbi (Kab. Bandung; $1180 \mathrm{~m}$ asl), and Ranca Upas (Kab. Bandung; $1740 \mathrm{~m}$ asl), respectively. Cyrtodactylus sp.1 "Cigorobog" was a male; observed sitting on a large rock $(\mathrm{d}=200 \mathrm{~cm}), 7 \mathrm{~m}$ from the waterfall in highland rainforest; TL/SVL $=1.15$; enlarged precloacofemoral scales $=1$ row; pore on the scales absent; groove on preanal region absent. Cyrtodactylus sp.2 "Kareumbi" was a male; observed perching on tree bark in highland rainforest; $\mathrm{SVL}=71.16 \mathrm{~mm}$ (tail broken and missing); 44 continuous precloacofemoral pores; groove on preanal region present. C. marmoratus was a male; observed perching on tree trunk in highland rainforest; TL/ $\mathrm{SVL}=0.88 ; 47$ continuous precloacofemoral pores; groove on preanal region present. These geckos were morphologically different and occupied different type of habitats, but need further evidence to validate their identity and position in the phylogeny (e.g., using molecular approaches). Hence, we hope that this information can be a trigger, particularly for local researchers, to further studies about these geckos, such as exploring and disentan- 


\section{JURNAL BIDDJATI}

http://journal.uinsgd.ac.id/index.php/biodjati

gling the potential of their diversity in West Java.

\section{New Record for Geographical Distribution of Amphibians in West Java}

Information concerning distribution of the species, particularly that has never been recorded previously is also very crucial supporting information for conservation priorities of the species (IUCN, 2019). To date, Leptophryne borbonica has only been reported from several national parks (NP) and nature reserve (NR) in Java: Ujung Kulon NP, Gunung Halimun-Salak NP, Gunung Gede-Pangrango NP, Bromo Tengger Semeru NP, and Nusakambangan NR (Iskandar, 1998; Kusrini, 2013). This study is the first that report L. borbonica from new locality in Java (Curug Cigorobog, Kab. Sumedang; see Figure 1; Table 2). Curug Cigorobog is the natural waterfall that considered as touristy area lately, located in the border of Taman Buru Masigit-Kareumbi (a conservation area). However, the surrounding area including soil and rock structure of the river and riparian vegetation of this locality has been changed into tourist attractions (e.g., permanent gazebos and bridge and river pools) (personal observation). This condition could be threatened L. borbonica habitat. $\mathrm{Ka}$ lophrynus minusculus was also recorded for the first time at Leuweung Sancang NR, Kab. Garut (see Figure 1; Table 2). Previously, $K$. minusculus has only been reported from Ujung Kulon NP. and Lampung (Iskandar, 1998; Kurniati, 2002; IUCN, 2019). The distance gap between previously known localities and the new locality of this species is also a challenge besides minimal information about its existence, since habitat of this species continues to decrease in southern part of West Java (Higginbottom et al., 2019). This condition could generate isolated population of this species. Both L. borbonica and K. minusculus are an example that conducting sampling in the region that has never been sampled is worthy, regardless the areas are within or outside conservation areas. The value of doing so is not only improving the species list in the region, but also improving the status of the areas. For example, the discovery of $K$. minusculus - a lowland specialist (Iskandar, 1998; Higginbottom et al., 2019), is hoped to increase the value of Leuweung Sancang NR as one of the remaining conservation areas with lowland habitat in West Java, besides Pananjung Pangandaran NR (Nurjaman et al., 2017). The management of the Curug Cigorobog could also take the discovery of $L$. borbonica into consideration while planning to expand the areas as tourist destination. To conclude, our study demonstrated that diversity of amphibians and reptiles in West Java is still underestimated. West Java has tremendous potential for comprehensive herpetofaunal research despite the availability of conservation areas are limited. We have demonstrated that conservation and non-conservation areas are both highly prospective for any types of research on amphibians and reptiles. The study should at least cover the information about species identity, biological aspects, habitat and ecology, population and distribution areas, which are the necessary for designing effective and efficient conservation priorities. Maintaining biodiversity while keeping the ecosystem balance are hard practice. Thus, natural resources utilization must be managed sustainably.

\section{ACKNOWLEDGEMENTS}

We thank BBKSDA Jawa Barat Wilayah III Ciamis for issuing research permit to conduct research at the Leuweung Sancang Nature Reserve area under SIMAKSI Number: SI.1392/BKW.III/08/2018. We also thank all BBKSDA staffs, Kang Ona, Sony Saefulloh, 


\section{JURNAL BIDDJATI}

http://journal.uinsgd.ac.id/index.php/biodjati

Marwan Nugraha, Ichsan Suwandi, Gina Afdila, Kresna Bayu Aji, Jehuda Christ Wahyu, Adenna Yuska Nurrahman, Sidiq Pambudi, and Pak Nandang for support during the fieldwork. We are grateful to Andri Irawan S. Martamenggala and Karlina Indraswari for valuable feedback for this paper.

\section{REFERENCES}

Agaton, M., Setiawan, Y. \& Effendi, H. (2016). Land Use / Land Cover Change Detection in an Urban Watershed: a Case Study of Upper Citarum Watershed, West Java Province, Indonesia. Procedia Environmental Sciences, 33, 654-660.

Arifin, U., Cahyadi, G., Smart, U., Jankowski, A. \& Haas, A. (2018). A New Species of the genus Pulchrana Dubois, 1992 (Amphibia: Ranidae) from Sumatra, Indonesia. Raffles Bulletin of Zoology, 66, 277-299.

Arifin, U. (2018). Phylogenetic systematics, diversity, and biogeography of the frogs with gastromyzophorous tadpoles (Amphibia: Ranidae) on Sumatra, Indonesia. Universität Hamburg.

Arifin, U., Smart, U., Hertwig, S. T., Smith, E. N., Iskandar, D. T. \& Haas, A. (2018). Molecular Phylogenetic Analysis of a Taxonomically Unstable Ranid from Sumatra, Indonesia, Reveals a New Genus with Gastromyzophorous Tadpoles and Two New Species. Zoosystematics and Evolution, 94(1), 163-193.

Bain, R. H., Lathrop, A., Murphy, R. W., Orlov, N. L. \& Cuc, H. T. (2003). Cryptic Species of a Cascade Frog from Southeast Asia: Taxonomic Revisions and Descriptions of Six New Species. American Museum Novitates, 1-60.

BBKSDA JABAR. (2018). Data dan Informasi: Statistik. Retrieved from http:// bbksdajabar.ksdae.menlhk.go.id/data-dan-informasi/statistik-2/.

BBKSDA JABAR. (2019). Kawasan Konsevasi. Retrieved from http://bbksdajabar.ksdae.menlhk.go.id/kawasan-konservasi/.

Bickford, D. P., Lohman, D. J., Sodhi, N. S., Ng, P. K. L., Meier, R., Winker, K., Ingram, K. K. \& Das, I. (2007). Cryptic Species as a Window on Diversity and Conservation. Trends Ecology and Evolution, 22, 148-155.

Bossuyt, F. \& Milinkovitch, M. (2002). Convergent Adaptive Radiations in Madagascan and Asian Ranid Frogs Reveal Covariation between Larval and Adult Traits. PNAS, 97, 6585-6590.

BPS. (2017). Badan Pusat Statistik: Sosial dan Kependudukan: Statistik Dasar. Retrieved from https://www.bps.go.id/ subject/12/kependudukan.html\#subjekViewTab3.

Chen, T. H., Chang, H. C. \& Lue, K. Y. (2009). Unregulated Trade in Turtle Shells for Chinese Traditional Medicine in East and Southeast Asia: the Case of Taiwan. Chelonian Conservation and Biology, 8(1), 11-18.

Colwell, R. K. (2013). EstimateS: Statistical Estimation of Species Richness and Shared Species from Samples. Version 9: User's Guide and Application. Retrieved May 20, 2019, from http://purl. oclc.org/estimates.

Cortés-Gomez, A. M., Ruiz-Agudelo, C. A., Valencia-Aguilar, A. \& Ladle, R. J. (2015). Ecological Functions of Neotropical Amphibians and Reptiles: A Review. Universitas Scientiarum, 20(2), 229-245.

De Lang, R. (2017). The Snakes of Java, Bali and Surrounding Islands. Frankfurt: Edition Chimaira. 


\section{JURNAL BIDDJATI}

http://journal.uinsgd.ac.id/index.php/biodjati

Fleming, I. A. \& Aagaard, K. (1993). Documentation and Measurement of Biodiversity. NINA Utredning, 50, 1-23.

Frost, D. R. (2019). Amphibian Species of the World: an Online Reference. Version 6.0. Retrieved from http://research.amnh. org/herpetology/amphibia/index.html.

Funk, W. C., Caminer, M. \& Ron, S. R. (2012). High Levels of Cryptic Species Diversity Uncovered in Amazonian frogs. Proceeding of the Royal Society Biology, 279(1734), 1806-1814.

Gibson, L., Lee, T. M., Koh, L. P., Brook, B. W., Gardner, T. A., Barlow, J., Peres, C. A., Bradshaw, C. J., Laurance, W. F., Lovejoy, T. E. \& Sodhi, N. S. (2011). Primary Forests are Irreplaceable for Sustaining Tropical Biodiversity. $\mathrm{Na}$ ture, 478(7369), 378-381.

Grismer, L. L. (2011). Lizards of Peninsular Malaysia, Singapore, and their Adjacent Archipelagos, Their Description, Distribution, and Natural History. Frankfurt: Ed. Chimaira.

Hamidy, A., Munir, M., Mumpuni, Rahmania, M. \& Kholik, A. A. (2018). Detection of Cryptic Taxa in the Genus Leptophryne (Fitzinger, 1843) (Amphibia; Bufonidae) and the Description of a New Species from Java, Indonesia. Zootaxa, 4450(4), 427-444.

Hartmann, L., Mecke, S., Kieckbusch, M., Mader, F. \& Kaiser, H. (2016). A New Species of Bent-Toed Gecko, Genus Cyrtodactylus Gray, 1827 (Reptilia: Squamata: Gekkonidae), from Jawa Timur Province, Java, Indonesia, with Taxonomic Remarks on C. fumosus (Müller, 1895). Zootaxa, 4067(5), 552-568.

Heyer, W. R., Donnelly, M. A., McDiarmid, R. W., Hayek, L. C. \& Foster, M. S. (1994). Measuring and Monitoring Biological Diversity: Standard Methods for
Amphibians. Washington: Smithsonian Institution Press.

Higginbottom, T. P., Collar, N. J., Symeonakis, E. \& Marsden, S. J. (2019). Deforestation Dynamics in an Endemic-rich Mountain System: Conservation Successes and Challenges in West Java 1990-2015. Biological Conservation, 229, 152-159.

Hof, C., Araújo, M. B., Jetz, W. \& Rahbek, C. (2011). Additive Threats from Pathogens, Climate and Land-Use Change for Global Amphibian diversity. Nature, 480(7378), 516-519.

Iskandar, D. T. (1998). Amfibi Jawa dan Bali (1st ed.; S. N. Kartikasari, Ed.). Bogor: Puslitbang Biologi - LIPI.

Iskandar, D. T. \& Erdelen, W. R. (2006). Conservation of Amphibians and Reptiles in Indonesia: Issues and Problems. Amphibian and Reptile Conservation, 4(1), 60-87.

IUCN. (2019). The IUCN Red List of Threatened Species. Version 2019-1. Retrieved from http://www.iucnredlist.org.

IUCN SSC Amphibian Specialist Group 2019. (2019). Leptophryne cruentata. The IUCN Red List of Threatened Species 2019: e.T138045255A3020276.

IUCN Standards and Petitions Subcommittee. (2017). Guidelines for Using the IUCN Red List Categories and Criteria. Retrieved from http://www.iucnredlist. org/documents/RedListGuidelines. pdf.\%0ATHE.

Kementrian Lingkungan Hidup dan Kehutanan. (2019). Peraturan Menteri Lingkungan Hidup dan Kehutanan Republik Indonesia Nomor P.106/MENLHK/ SETJEN/KUM.1/12/2018. Retrieved from https://graccess.co.id/assets/document/Permen P106.pdf.

Kieckbusch, M., Mecke, S., Hartmann, L., 


\section{JURNAL BIDDJATI}

http://journal.uinsgd.ac.id/index.php/biodjati

Ehrmantraut, L., O'Shea, M. \& Kaiser, H. (2016). An Inconspicuous, Conspicuous New Species of Asian pipesnake, genus Cylindrophis (Reptilia: Squamata: Cylindrophiidae), from the South Coast of Jawa Tengah, Java, Indonesia, and an Overview of the Tangled Taxonomic History of C. ruffus (Laurenti, 1768). Zootaxa, 4093(1), 1-25.

Koch, A., Ziegler, T., Boehme, W., Arida, E. \& Auliya, M. (2013). Pressing Problems: Distribution, Threats and Conservation status of the Monitor Lizards (Varanidae: Varanus spp.) of Southeast Asia and the Indo-Australian Archipelago. Herpetological Conservation and Biology, 8(3), 1-62.

Kolbe, J. J., Lavin, B. R., Burke, R. L., Rugiero, L., Capula, M. \& Luiselli, L. (2013). The Desire for Variety: Italian Wall Lizard (Podarcis siculus) Populations Introduced to the United States via the Pet Trade are Derived from Multiple Native-Range sources. Biological Invasions, 15(4), 775-783.

Kurniati, H. (2002). Frogs and Toads of Ujung Kulon, Gunung Halimun and Gede-Pangrango National Park. Berita Biologi, 6(1), 75-84.

Kurniati, H. (2003). Amphibians and Reptiles of Gunung Halimun National Park, West Java, Indonesia: An Illustrated Guide Book (1st ed.). Cibinong: Research Center for Biology - LIPI.

Kusrini, M. D. (2007). Konservasi Amfibi di Indonesia: Masalah Global dan Tantangan. Media Konservasi, 7(2), 89-95.

Kusrini, M. D. (2013). Panduan Bergambar Identifikasi Amfibi Jawa Barat (1st ed.; Y. A. Mulyani \& A. Hamidy, Eds.). Bogor: Pustaka Media Konservasi.

Kusrini, M. D. \& Alford, R. A. (2006). Indonesia's Exports of Frogs' Legs. TRAF-
FIC Bulletin, 21(1), 13-24.

Kusrini, M. D., Lubis, M. I., Endarwin, W., Yazid, M., Darmawan, B., Ul-Hasanah, A. U., Sholihat, N., Tajalli, A., Lestari, V., Utama, H., Nasir, D. M., Ardiansyah, D. \& Rachmadi, R. (2017). Elevation Range Shift After 40 years: The Amphibians of Mount Gede Pangrango National Park revisited. Biological Conservation, 206, 75-84.

Lever, C. (2003). Naturalized Reptiles and Amphibians of the World. New York: Oxford University Press.

Mace, G. M., Norris, K. \& Fitter, A. H. (2012). Biodiversity and Ecosystem Services: a Multilayered Relationship. Trends in Ecology and Evolution, 27(1), 19-26.

Mumpuni. (2001). Keanekaragaman Herpetofauna di Taman Nasional Gunung Halimun, Jawa Barat. Berita Biologi, 5(6), 711-720.

Nurjaman, D., Kusmoro, J. \& Santoso, P. (2017). Perbandingan Struktur dan Komposisi Vegetasi Kawasan Rajamantri dan Batumeja Cagar Alam Pananjung Pangandaran, Jawa Barat. Jurnal Biodjati, 2(2), 167-179.

O’Connell, K. A., Smart, U., Sidik, I., Riyanto, A., Kurniawan, N. \& Smith, E. N. (2019). Diversification of Bent-Toed Geckos (Cyrtodactylus) on Sumatra and West Java. Molecular Phylogenetics and Evolution, 134, 1-11.

Prasetyo, L. B., Kartodihardjo, H., Adiwibowo, S., Okarda, B. \& Setiawan, Y. (2009). Spatial Model Approach on Deforestation of Java Island, Indonesia. Journal of Integrated Field Science, 6, 37-44.

Riyanto, A. (2008). Komunitas Herpetofauna di Taman Nasional Gunung Ciremai, Jawa Barat. Jurnal Biologi Indonesia, 4(5), 349-358.

Riyanto, A., Bauer, A. M. \& Yudha, D. S. 


\section{JURNAL BIDDJATI}

http://journal.uinsgd.ac.id/index.php/biodjati

(2014). A New Small Karst-Dwelling Species of Cyrtodactylus (Reptilia: Squamata: Gekkonidae) from Java, Indonesia. Zootaxa, 3785(4), 589-599.

Riyanto, A., Grismer, L. L. \& Wood, P. L. (2015). The Fourth Bent-Toed Gecko of the Genus Cyrtodactylus (Squamata: Gekkonidae) from Java, Indonesia. Zootaxa, 4059(2), 351-363.

Riyanto, A. \& Kurniati, H. (2014). Three New species of Chiromantis Peters 1854 (Anura: Rhacophoridae) from Indonesia. Russian Journal of Herpetology, 21(1), 65-73.

Riyanto, A., Munir, M., Martamenggala, A. I. S., Fitriana, Y. S. \& Hamidy, A. (2019). Hiding in Plain Sight on Gunung Muria: A New Species and First Record of Rock Gecko (Cnemaspis Strauch, 1887; Squamata, Gekkonidae) from Java, Indonesia. Zootaxa, 4608(1), 155-173.

Saber, S., Tito, W., Said, R., Mengistou, S. \& Alqahtani, A. (2017). Amphibians as Bioindicators of the Health of Some Wetlands in Ethiopia. The Egyptian Journal of Hospital Medicine, 66, 66-73.

Schneider, L., Maher, W., Green, A. \& Vogt, R. C. (2013). Mercury Contamination in Reptiles: An Emerging Problem with Consequences for Wild Life and Human Health. In K.-H. Kim \& R. J. C. Brown (Eds.), Mercury: Sources, Applications and Health Impacts (pp. 173-232).

Senior, M. J. M., Brown, E., Villalpando, P. \& Hill, J. K. (2015). Increasing the Scientific Evidence Base in the "High Conservation Value" (HCV) Approach for Biodiversity Conservation in Managed Tropical Landscapes. Conservation Letters, 8(5), 361-367.
Simoons, F. J. (2014). Food in China: a Cultural and Historical Inquiry. Boca Raton: CRC Press.

Sodhi, N. S., Posa, M. R. C., Lee, T. M., Bickford, D., Koh, L. P. \& Brook, B. W. (2010). The State and Conservation of Southeast Asian biodiversity. Biodiversity and Conservation, 19, 317-328.

Stuart, B. L., Inger, R. F. \& Voris, H. K. (2006). High Level of Cryptic Species Diversity Revealed by Sympatric Lineages of Southeast Asian forest frogs. Biology Letters, 2(3), 470-474.

Sy, E. Y. (2015). Checklist of Exotic Species in the Philippine pet trade, II. Reptiles. Journal of Nature Studies, 14(1), 66-93.

Uetz, P., Hallermann, J. \& Hosek, J. (2019). The Reptile Database. Retrieved from http://reptile-database.reptarium.cz/.

UNEP-WCMC. (2014). Checklist of CITES species. Retrieved from http://checklist. cites.org.

Valencia-Aguilar, A., Cortés-Gómez, A. M. \& Ruiz-Agudelo, C. A. (2013). Ecosystem Services Provided by Amphibians and Reptiles in Neotropical ecosystems. International Journal of Biodiversity Science, Ecosystem Services and Management, 9(3), 257-272.

Veith, M., Kosuch, J., Ohler, A. \& Dubois, A. (2001). Systematics of Fejervarya limnocharis (Gravenhorst, 1829) (Amphibia, Anura, Ranidae) and Related Species. 2. Morphological and Molecular Variation in Frogs from the Greater Sunda Islands (Sumatra, Java, Borneo) with the Definition of Two Species. Alytes, 19(1), 5-28. 